\title{
Paul's Teachings on the Uniqueness and Supremacy of Christ in Colossians 1:12-23 and Its Implications for Christianity in Africa
}

\author{
Valentine Chukwujekwu Mbachi and John Uchendu
}

\begin{abstract}
This article examines Paul's teaching on the uniqueness and supremacy of Christ and its implications for Christianity in Africa. The approach is analytical or qualitative. The historical-critical method and contextual tools are used in the interpretation of the biblical text. The study reveals that Christianity in Africa shares similar threats of heresy to that of the Church at Colossae which, of course, holds implications for Christianity in Africa such as: that Christ must be a living reality in one's life without which he/she is not worth being classified as a Christian, that the one professing to be a Christian must not only be rooted in Christ but must be built up in Him as well, that Christians in Africa should realize that when believers are part of the body of which Christ is the head, there is no need to fear or manipulate any other spiritual beings, that subjugated powers cannot harm the person who is in Christ for their ultimate overthrow in the future is assured, that Christians in Africa have no cause to pay homage to any lesser supernatural beings, that Christians are not to follow ceremonies, rituals, initiations and restrictions in order to be saved, that Christians in Africa must not obtain secret or acquire an exoteric knowledge in order to be saved or be liberated from the clutches of evil powers, and that they should shun combining aspects of several religions given that they have everything since they have Christ. This, therefore, spells the need to take Christian discipleship very seriously in African Churches.
\end{abstract}

\section{Introduction}

Africa is perhaps one of the geographical areas that has witnessed the flourishing of Christianity the most in the recent times. Also, owing to various cultural backgrounds and colonial experiences, Christianity in Africa is possibly the most diversified. The missionaries had emphasized the power of Jesus to save the soul from the power of sin, but the power of Jesus which destroys the power of the devil and delivers from all evil spiritual and elemental forces and diseases was not enthusiastically proclaimed. The most urgent need now appears to be the interpretation of the Bible in such a way that the Word will become incarnate (as it were), once again in the language and life of the people of Africa. Thus, while the emphasis has been on enculturation, contextualization or indigenization, there is still a crying need to be concerned about syncretism which is the mixing of incompatible religious ideas and practices. Equally, we need to be concerned about the heresies of syncretism, of the direct and indirect denial of the uniqueness and total adequacy of Jesus Christ, of the denial of the completeness of our salvation in Him and through Him. This is a challenge to Christianity particularly when the converts to Christianity come from traditional religious background. Paul's letter to the Colossians reflects such a situation. Paul was writing to a young Gentile church that was apparently under the intense pressure to syncretise their new Christian faith by adding elements from other traditions and teachings, including their own past religious experience.

The uniqueness and supremacy of Christ runs like a thread throughout the New Testament. However, for an in depth study, relevant to the issue at hand, and to conserve space, we would like to limit ourselves to Colossians 1:12-23. This article aims to examine the Colossian heresy and see its implications for Christianity in Africa with particular reference to the uniqueness and supremacy of Christ. The historicalcritical method and contextual tools are used in the interpretation of the biblical text.

\section{Issues that Plagued the Colossian Church}

In his letter to the Colossians, Paul did not lay out the heresies of the time, but the heretical teachings he was addressing can be identified by considering the responses he gave to them: 
(a) First, Paul highlighted the supremacy of Christ, and this emphasis suggests that the false teachers were teaching that the simple truth preached by Jesus and preserved in the gospel was not enough. It had to be filled out by more philosophical considerations. Paul thoroughly rejected these philosophical or fanciful speculations that seek to undercut the high Christology he advocated. He enjoins the Colossians not to quit using their minds, but to focus on Christ as the foundation of their faith.

(b) Paul warned against being deceived by human philosophy, that is, empty human speculations without divine revelation. Likely, he was referring to an early form of Gnosticism, which arose in the second century. The message of the heretics was also that the Colossians were still under the influence of the elemental spirits of the universe, especially of the stars and planets (Col. $2: 8,20)$. As a result, they needed a special knowledge, beyond that which Jesus could give in order to be set free. Paul taught that when we know Jesus Christ, we don't need to investigate other religions, cults, or unbiblical philosophies. Christ alone holds the answer to the true meaning of life, because Christ is life. He is the unique source for the Christian life. Consequently, no Christian should seek for anything beyond what Jesus has made available.

(c) False teachers were seeking to impose circumcision upon the Colossian Christians. They were teaching that faith was not enough, and that circumcision was necessary for salvation. In other words, a mark in the flesh had to be supplemented to the attitude of the heart. However, Paul counteracted this teaching by telling the Colossians that circumcision is a spiritual act whereby Christ cuts away the old unregenerate nature of rebellion against God and imparts to the Christian his spiritual and resurrection life (Col. 2:11-12). Paul brings it home to the Colossians that circumcision is of the heart.

(d). Errorists wanted to lay down rules and regulations for self-denial. They intended to introduce all manner of dietary regulations about what might be eaten and drunk and about what days to be observed as festivals and fasts. Against the inclusion of Jewish ascetic dietary rules as being necessary for salvation, Paul taught that a Christian is freed from legal and ceremonial obligations of this kind.

(e). The Colossian heretics were seeking to impose the worship of angels on the church (Col. 2:18). They were teaching that Jesus was only one of many intermediaries between God and humans, and that these intermediaries must receive their worship. To Paul, calling on angels would be displacing Jesus Christ as the supreme and sufficient Head of the Church.

Having gone through these issues listed above, two things can be noted: (a) the content of the heresy appears diverse. It contains a mixture of Jewish legalism, Greek speculation, and the mysticism of the Orient. Perhaps, some of the elements later emerged in fully developed Gnosticism. And, (b) the common thread that is conspicuous in the false teachers' message is that Jesus Christ and his teachings and work were not in themselves sufficient for salvation. As far as they were concerned, Jesus Christ was not sufficient, not unique but merely one among many manifestations of God and it was necessary to know and serve other divine powers in addition to him.

\section{Scholarly Views cum Historical Perspective}

The identity of the Colossian heretics has been a difficult problem for New Testament scholarship to solve. Houlden (1970) and Eadie (1979) regard the group as a Jewish sect, but Zan (1970) denies such a connection. Scholars like O'Brien (1982), and Barclay (2009) have tried to root the heretics teachings in some form of early Gnosticism, in Greek philosophy, or in Jewish mysticism, all without full success. Flemming (2005) thinks that the Colossian problem should be seen as a kind of "syncretistic stew made up of a number of religious ingredients" (215). However, in the light of the discovery of the Dead Sea documents, Moule (1968) opined that there may be justification for the comparison of the Colossian heresy with Essenism.

The works of Baur and that of Lightfoot were probably predominant over others in the nineteenth century. F. C. Baur was not only uncertain of the genuineness of the epistle but also dated it after the death of the Apostle Paul. This became a springboard for other scholars to come up with their own contextual convictions. Baur's work led to understanding Christian works in their contextual settings and paved the way for the comparisons between Christianity and nonChristian parallels. In many ways, all subsequent study reacts to Baur; some support him, some modify him, and others oppose him. Lightfoot (1817) saw the problem as an incipient Jewish Gnosticism which characterised the Essenes. The religious and philosophical parallels pointed to an early date for the epistle. The idea of incipient Gnosticism is one that remains viable one hundred years after Lightfoot's commentary.

Scholars in the twentieth-century developed and shaped one or more of these ideas from the nineteenth century. While biblical exegetes like Dibelius (1953) and Lohse (1971) held onto the Gnostic or pre-Gnostic context, others such as Bruce (1957), Bandstra (1974) and O'Brien (1982) clang tenaciously to a more Jewish context. The first major treatise of the twentieth century was written by Dibeius. He studied the Isis initiation in Apuleius and was impressed particularly by a technical use of term embateuo, suggesting that Colossians was 
addressing a similar initiatory rite. For him, Colossians provided a proof that Christianity had joined with a mystery cult of the "elements" by about A. D. 56. This probably occurred before the time of Paul. Paul's task, therefore, was to demonstrate the distinction between the cult and Christianity. Many objections arose to Dibelius' thesis. Dibelius failed to explain the distinctive element of Christianity that made it survive. For him, its survival depended on its restrictedness, but the restricted nature was unexplained.

Later scholars have modified Dibeliu's position. Bornkamn (1948) argues that the problem was Gnosticized Judaism that added pagan elements, including Iranian-Persian elements and Chaldean astrology, and syncretism was the result. Lyonnet (1956) thinks that the terms used to support the ties between Christianity and Gnostic cults occurred outside Gnostic circles as well. Particularly, they often occurred in Jewish (Christian) contexts. He concluded that the opponents were Christians attracted to Judaism and that the Colossian heresy was some form of Judaism. Most likely it was typical of reactionary Judaism, such as practiced at Qumram, since many of the terms occur in that literature.

Historical inquiry reveals a sizeable Jewish community in the Lycus Valley at the first century. Josephus recorded that Antiochus the Great (223-187 B. C) imported two thousand Jewish families from Mesopotamia and Babylon to Lydia and Phrygia. However, Lightfoot (1817) faulted this calculation. The entire Jewish population would probably be much larger than this partial estimate implied. The attraction of the Jews to the areas was of some concern to the Jewish scholars. Contextual studies not only reveal a large and vocal Jewish element in the area, but also reveal that many Jews converted to Christianity.

Keener (1993) thinks that Jewish Sibylline oracles may issue from that region, and the activity of later Christian Montanists there suggests the possibility of ecstatic elements from both of these in local Judaism (Acts 2:18). He notes that Acts testifies that Paul was preaching Christ to philosophically minded audiences in the period, and that letters like Ephesians and Colossians give us an indication of Paul's grasp of Greek philosophy and also some of the popular philosophical ideas that permeated both Gentile and Jewish thought in mid-first century Asia Minor.

Admittedly the above historical survey is not an elaborate one for a work of this nature, still the important points in this discussion are:

(a) It helps us to appreciate the rich cultural backgrounds that played into the problems Paul was addressing in Colossae; (b) It helps us to find out for ourselves that the identity of the false teachers is not easy to specifically pin down; and

(c) That the best way to come to grips with the problem at Colossae is to go to the biblical text itself.

\section{Exegesis and Discussion}

In the passage under consideration, Paul speaks of the distinctive relation of Christ to God. As a Revealer and Redeemer of God, Christ bears the mark of definiteness and wholeness (Col. 1:13). Through Christ God has delivered us from the power of darkness and translated us into that of light and freedom. The kingdom of skotos (darkness), which is the personified spiritual forces worshipped by the Colossians, is mentioned in contrast to phos (light) (Col. 1:12-13). The word mathistemi (to remove, transfer) is of special interest here. It reminds one of what was obtainable in an ancient world when a land was conquered perhaps by another king, the conqueror usually transferred the people of his conquered land en mass. For instance, the people of the northern kingdom of Israel were taken captive to Assyria while the southern Israelites were taken to Babylon as captives. The coming of God into the world through Jesus Christ to save sinners can be likened to a glorious light breaking on darkest night. It is a transference from guilt and condemnation to forgiveness and justification. The idea of the Church entering the Promised Land like the old Israel is present in the use of the word kleros (inheritance) (Col. 1:12). In Jesus we have apolutrosis (redemption). Our redemption is a release (aphesis) from sin. The idea of Exodus and the year of Jubilee is here. This is a direct attempt by Paul to counteract the Colossian heresy which thinks of redemption only in terms of being freed from angelic powers and elemental spirits of the universe.

Flemming (2005) states concisely that, "Paul affirms the supremacy of Christ most clearly in the magnificent Christological hymn of Colossians 1:15-20. This passage speaks forcefully to the concerns of the context and lays a foundation for Paul's Christological response to the Colossians' syncretism" (220). Who (Hos), which opens verse 15, carries us back at once to huios (son) of verse 13. Jesus, the Son of God who died on the cross, is the eikon (image) of the invisible God. Eikon is different from homoioma, which only expresses a mere resemblance. Eikon (image) implies representation or the exact image of the archetype (cf. Col. 1:14, 2:9; Phil. 2:6; Heb. 1:3). The degree of resemblance between the archetype and the copy must be determined by the word's context but could range from a partial or superficial resemblance to a complete or essential likeness. Given Colossians 1:19 and 
Colossians 2:9 eikon here signifies that Jesus is an exact, as well as a visible, representation of God. Chrysostom (cited in Eadie 1979) speaks of it as "a faithful likeness in everything" (42). In other words, by the use of eikon Paul means that Jesus is the perfect manifestation of God. He fully reveals God to humankind in a form which they can see, know and comprehend. In His incarnate state, Jesus brought God to humanity and placed God under the cognizance of their very senses. Human beings saw Jesus manifest various forms of overt behaviour such as acting, weeping and speaking, as well as witnessing His suffering on the cross. The summary of Paul's argument is that God did not make Himself known through a series of emanations, but once and for all exceptionally in Christ. Besides, the idea of Christ being the image of God reminds us of the creation story: "God said, let us make man in our own image ... So God created man in his own image, in the image of God created he him” (Gen. 1:26, 27). God's original purpose at the creation was that man should be nothing less than the eikon of God, but as a result of sin, humankind fell short of that ideal goal of creation. Be that as it may, Jesus not only revealed God perfectly as God's eikon but being a human being in the full sense of the word, demonstrated what human beings ought to be.

Christ is also prototokos pases ketiseos (the firstborn of all creation). In Africa, the "firstborn" is the eldest child in a family. He sometimes goes with the name Afu nwa echeta nna ("once you see the son, he reminds you of the father"). He is regarded as the "beginning of his father's strength and might" in the same manner and way Jacob used it for Reuben in Genesis 49:3, and as "the opener of womb" as it was used in Exodus 13:2. The usages, however, point to both paternal and maternal affiliations for the child. It is a position that is widely recognised in Africa and the accompanying privileges are greatly valued. The rights and privileges of the first-born include, and are not limited to, family leadership, a special blessing from the father, larger inheritance, and honoured place during festivities. He sometimes acts on behalf of the father. When the father is no more, he assumes the full role of a father to the siblings. Nobody in the family can act without seeking his approval. He is also referred to as the family head. In other words, he commands a measure of authority. But, when Paul speaks of the Son as the prototokos of all creation, he was thinking far beyond the African concept of the first-born. In fact, he might not be thinking within the earthly time frame at all, for in Jewish thinking, prototokos does not imply creation. Kasemann (1964) considers this idea when he suggests Colossians 1:15 may be a reference to the Gnostic heavenly human who was to be born in the likeness of the Father, subject himself to the powers of fate in the world, and be exalted above all to pave the way to the divine realm for mortal humankind. He says further that this describes the original Man who stood in a special relation to God and shared his throne. But it should be noted that at the time Paul was writing, Gnosticism was not yet fully grown. Barclay (2009) is of the opinion that if we wish to keep the time sense and the honour sense combined, the rendering may be "He was brought to birth before all creation" (138). Athanasius (cited in Abogunrin, 2002), while replying to Arius' interpretation of Proverbs 8:22, drew attention to Colossians 1:16 and added that, "if all creatures were created in him, he is other than the creatures, and he is not a creature but the Creator of creatures".

Christ is the origin and the goal of the whole creation. He is the creative agent of "all things"-things in heaven and things on earth. In other words, He is the Creator of all things (Col. 1:16a); Mediator ("through him"); Goal ("for him" Col. 1:16b) and Sustainer of the whole creation. He has no parallels or rivals. All cosmic powers are dependent on Him, whether thrones, principalities, or powers. In Him (Christ), the whole creation holds together. "Thrones", "lordships", "powers", and "authorities" were different grades of angels having their places in different spheres of heaven. O'Brien (1882) thinks that it is hostile rather than friendly powers Paul had particularly in view. This is very much appropriate given the fears that Paul's readers apparently held for cosmic powers and the concern of the rival teachings to appease them. For Paul, Jesus is not one of the created angelic beings but He is the Son of God. Barclay (2009) captures it correctly when he said that the "Son is the beginning of creation, and the end of creation, and the power who holds creation together, the Creator, the Sustainer, and the Final Goal of the world" (139).

Verse 18 opens with kai autos estin he kephale tou somatos tes ekklesias which means that Christ Himself is the head of the body which is the Church. It means, "he himself" and "he and no other". The one who is the creative centre and focus of the universe (Col. 1:16) and the source of its cohesion (Col. 1:17b) is also (kar) "the head of the Body, which is the Church". Houlden (1970) thinks ekklesias here refers to the whole creation and that it probably represents the idea of the Logos soul indwelling the whole cosmos. He sees affinities between this and the Adam of Genesis 1 who was made the head of all creation. But the errorists have challenged Christ as the sole authority over all else in

\footnotetext{
${ }^{1}$ Abogunrin, in lecture, based on: Select Treatises of St. Athanasius in Controversy with the Arians, Vol. 2. John Henry Newman. 2016. Charleston, SC: BiblioBazaar.
} 
creation and Paul wants to show that Jesus Christ is not only the ultimate meaning and goal of the old creation, he is also the head of the new creation which is the church. The previous verse shows Christ's qualification for such a headship. These are his divine nature, his supremacy over all else in creation and his holding the world together. Here, Paul shows that the old creation and the new creation, the church, are under one administration, headed by Jesus who is King of kings and Lord of lords.

Christ is prototokos ek ton nekron ("the first-born from among the dead"). Harris (2010) thinks that this phrase may define even more precisely the ground for Christ's headship. He is the head of the Church in that (hos) he is the beginning (arche) being the first (prototokos) to rise from the dead (Acts 26:23) and never to die again (Rom. 6:9). Harris suggests that the phrase may proffer a second ground for that headship: not only is Jesus the cause of the Church's existence and the origin of vitality (arche); he is also the pioneer and guarantor of a resurrection from death to immortality. His resurrection inaugurates a new creation and thus becomes the source of new life. The resurrection of Jesus was an event which was at the centre of all thinking, belief, and the experience of the early Church. Unlike what we have in the myths of dead heroes and founders of great religions, Christ is alive forevermore. Consequently, Christians experience his living and abiding presence. In the light of this therefore, Achtemeier, Green \& Thompson (2001) think that "When Christians are part of the body of which Christ is head, there is no need to fear or to try to manipulate any other spiritual beings" (410).

Moreover, Paul declares that in Christ "all the pleroma (fullness) of deity dwells bodily" (Col. 2:9). Paul's use of the term pleroma (fullness) raises an interesting question. Has he borrowed it from the heretics and suffused it with new Christological content? There is no way one can find out. For Wright (1986), the Colossians have no cause to pay homage to any lesser supernatural beings or angel-intermediaries. This is simply because Christ is not just one among the many competing gods or powers. He reigns supreme over every ruler and authority (Col. 1:10). The totality of God, the entirety of His attributes and divinity, is pleased to dwell in Christ.

Again, Paul speaks of reconciliation in cosmic terms (apokatallazai ta panta Col.1:20). He applies it to Colossians, repeating the theme of reconciliation accomplished by God through the death of Christ (Col. 1:21-22). It is not only here that Paul thinks in this direction (cf. Eph. 1:10; Rom. 5:10 ff, 8:19-23; II Cor. $5: 19 \mathrm{ff})$. This is perhaps an attempt to show us as in Romans 8:19-23 that this is God's world and it is a redeemed world because in some amazing way God in Christ was reconciling the whole universe to Himself.
For all its intents and purposes, Paul was labouring to show that the cosmic powers which the Colossians feared and venerated also stand in need of reconciliation. The idea of reconciliation which includes all creation is in a sense strange. Be that as it may, the cosmic redemption of Romans 8:19-23 and the acceptance of the authority of Christ by the whole cosmos (Phil. 2:9-11) can only be meaningful in terms of cosmic reconciliation. Origen (cited by Barclay, 2009: 143) opined that the phrase referred to the devil and his angels, and he believed that in the end even they would be reconciled to God through the work of Christ. In the same vein, Theodoret and Erasmus (cited by Barclay, 2009: 144) thought that the angels were reconciled to humankind rather than God. They held the opinion that the angels had wanted to destroy humanity because of what humanity had done against God, but through the work of Christ they saw how much God still loved humanity and therefore their wrath was removed. This interpretation is close to the African conception of God, divinities, ancestors, spirits and humans, but the interpretation is not likely in the light of the Colossian situation. Alford (1976) thinks:

No reconciliation must be thought of which shall resemble ours in its process-for Christ took not upon him the seed of angels, nor paid any propitiatory penalty in the root of their nature. But, as much as he is their head as well as ours, for much as in him they, as well as ourselves, live and move and have their being, it cannot be but that the great event in which he was glorified through suffering, should also bring them nearer to God; who subsist in him in common with all creation (124).

Finally, verse 23 highlights four motifs found in Colossians 1:4-6 in the thanksgiving section: faith, hope, the hearing of the gospel, and its worldwide dissemination.

\section{Features of Christ's Uniqueness and Supremacy in Pauline Teaching}

As a consequent of Paul's teaching in Colossians 1:15-23, the following features of Christ's uniqueness can be delineated:

(a) The Redeemer: Jesus Christ is our Redeemer. This entails being transferred from darkness to light, from slavery to freedom, from guilt to forgiveness, from the kingdom of darkness to the kingdom of God, and from the power of Satan to the power of God.

(b) The Image of God: Jesus Christ is the Image of the invisible God. The invisible God, who dwells in unapproachable light is visibly expressed in Christ. He 
is the outward projection of God; indeed, He is God's visible expression.

(c) The First-born of all Creation: Jesus Christ is not part of the creation but He Himself is the creator. Christ is the origin and the goal of the whole creation. $\mathrm{He}$ is the creative agent of "all things"-things in heaven and things on earth. In other words, He is the Creator of all things (Col. 1:16a); Mediator ("through him"); Goal ("for him" Col. 1:16b) and Sustainer of the whole creation. He has no parallels or rivals. All cosmic powers are dependent on Him, whether thrones, principalities, or powers. In Him (Christ), the whole creation holds together.

(d) The Beginning and the First-born from among the Dead: Jesus Christ is the Beginning and the First-born from among the Dead. Consequently, He is before and preeminent over all creation. This equally implies the subsequent resurrection of all those for whom He died.

(e) The Fullness God: Jesus Christ is fully God. The full and complete Godhead with all that it represents resides in Christ. In Christ all the fullness of Deity lives in bodily form. In other words, He is entirely God, Head over old and new creation.

(f) The Reconciler: Jesus Christ is the Reconciler of all things. Everything that is in rebellion against God will be brought under Christ's power and will submit to Him as the Head of the new creation. It does not mean however, that all people are reconciled irrespective of their wills. It does mean that whoever rejects Christ's offer of reconciliation remains God's enemy.

\section{Colossian Heresy and Christianity in Africa}

The heresy at Colossae attacked the total adequacy, uniqueness and supremacy of Jesus Christ over all else in creation. Perhaps, it is why the book opens with a lofty view of Jesus Christ and throughout the book we have a strong insistence on his completeness and finality, as the image of the invisible God, in whom the fullness of Deity dwells (Col. 1:15ff). Abogunrin (2002) thinks that there are two main reasons for the Colossian error. First, the teachings reflect the dualism of antagonism between spirit which is good and matter which is intrinsically evil. The material body is seen as the prison house of the rational soul. This led to the practice of asceticism which was aimed at liberating the soul from the bondage and passions that have their seats in the flesh. Once any human recognizes the divine nature of his or her soul, there is war without resolution between it and the body. The emancipation of the soul could only be achieved by rigorous asceticism and repression of the body. When the soul does gain victory over the body, it attains its destiny of union with God or identity with the Ultimate Reality. Abogunrin comments (pers. comm.), "By this the freed man or woman possess an esoteric knowledge or psycho-physical power that controls the spiritual world." Second, he notes that "there is a kind of Oriental theosophy which defines the relation between the Deity and the sinful world by means of a series of intermediary existences. The major problem is how to gain entrance to the divine Presence. God's presence was believed to be distributed through a series of emanations stretching from heaven to earth." This is what Paul calls ta stoicheia tou kosmou (the elemental spirits of the world). Since they controlled the entrance to the divine Presence, humans must be liberated from them and at the same time seek their favour by paying homage to them and keeping the taboos proceeding from them. The ancient world was dominated by the thought of the influence of the stars. The most powerful and wisest of human beings could not act without consulting them. The Colossian heresy made the most of demon spirits which Paul calls archai (principalities) and ezousiai (powers). These demonic powers were in one sense, intermediaries, and in another sense, barriers between heaven and earth.

In the same way, Africans believe in an infinite number of spirits which are equally good and bad spirits. The divinities are intermediaries between God and man. Africans still live in a demon-haunted universe. Belief in witches and wizards is common. Natural forces like thunder, lightening, wind and rain have spiritual forces controlling them. Mountains, rivers, lakes, forests, valleys, trees and groves are inhabited by spirits which can be tapped either for blessings or for curses and harm. Consequently, Africans cannot help living under constant fear of the world believed to be infested by spirits and demons. There are people who are believed to be gifted to manipulate these spiritual forces either for good or for evil. These people are greatly feared by the people. The divinities are many and their number varies from locality to locality. For instance, Awolalu and Dopamu (1979), and Abogunrin (2002), noted that among the Yoruba, the number varies between 201, 401, 600 and 1700 while among the Igbo, Nupe, Akan, and Mende, the number is not as large. All these divinities and some of the spirits are worshipped. Traditionally, no person would venture to act without consulting a particular or family divinity. Not surprisingly, under these prevailing circumstances the gods and the spirits control access to the divine Presence.

However, not all Christians fall prey to this captivity today. A good percentage of Christians have absorbed the teachings of Paul. These Christians are mainly from Evangelical, Pentecostal and Charismatic Movements. Quite a few are from mainstream churches. That does 
not mean that there are no false Pentecostal, Charismatic and Evangelical Movements as a lot of cultists, spiritualists and magicians have gone into the ministry to propagate their selfish interests. These false ministers speak in strange tongues and claim to cast out demons and raise the dead. Contrary to our expectations, a good percentage of Christians from mainstream churches and African Independent Churches still fall prey to the captivity. At present, we are witnessing an exodus of some African youths from the churches and a return to idol worship. A resurgence of idol worship is well attested to in most African communities. It is a sad statistic that the number of people who are genuinely Christians in Africa today is declining. About two thirds of them are nominal Christians. This is because there is a widespread misconception of Christianity in the continent. Christianity is not primarily a creed, but some Christians in Africa think it is. They imagine that if they can recite the Apostles' Creed from beginning to end without any mental reservations, this will make them a Christian. Some Christians in Africa think that Christianity is primarily a code of conduct and even contradict the people that hold that Christianity is primarily a creed. Others think that Christianity is primarily a system of religious worship and cluster of ceremonies. Stott (1991) states categorically that "Christianity is neither a creed, nor a code, nor a cult, important as these are in their place. It is in essence neither an intellectual, nor an ethical nor a ceremonial system. Indeed, we must go further. It is not all three put together. It is perfectly possible (though rare because difficult) to be orthodox in belief, upright in conduct and conscientious in religious observances, and still to overlook the heart of Christianity" (15).

If the essence of Christianity is neither a creed, nor a code, nor a cult, what is it? Stott (1991) in clear and strong terms writes: "It is Christ! It is not primarily a system of any kind; it is a person, personal relationship to that person. Then other things fit into shape-our beliefs, and our private and public devotions" $(16,18)$. Stott captures the missing piece in the life of many professing Christians in Africa. Many uninformed scholars speak bogusly about the teeming population of Christians in Africa. Yet, without Christ Christianity is reduced to mere activities without spirit, and a body that is bereft of the breath of life. What more! Some of these Christians quest for additions to Christ.

The Colossian heretics were teaching that they needed something more than Jesus Christ to span the gulf between God and humanity and to liberate humanity from the elemental spirits of the universe. They felt that the gospel message was too simple to be rational and that instead of the simplicities of the gospel they needed more elaborate and complex system which insisted on food taboos, ritual, special holy days, festivals and Sabbaths. In the same vein, in Africa today, thousands, and tens of thousand of professing Christians are still involved in idol worship either directly or indirectly. It is ironical that while Jesus might be rated high as a mediator between God and humans, He is not accepted as the only way to God but rather as one of the intermediaries or one of the divinities. Moreover, there is a veneration and worship of ancestors to whom prayers are made. Some Christians are not exonerated from this. To this end, Abogunrin (2002) queried, "Is there any difference between such Christians and the Christians who venerate Mary, saints or angels and pray through them to God?" These powers which the Colossians tried to placate were angelic beings. The veneration and worship of angels is predominant in African Independent Churches.

The teaching in Colossae and the syncretistic practices in some churches in Africa today reduce Jesus to the status of an angelic being or one of the divinities or spirits needed to span the gulf or chasm between God and humanity. Access to God is only possible through the veneration of these go-between powers. The Apostle Paul refutes these teachings and practices by speaking of the uniqueness of Christ as the only Redeemer and Mediator between God and humankind. For Paul, the Colossian heresy adversely affects the assurance that life is secured in the hand of God through his only begotten Son, Jesus Christ, and thereby creates uncertainty and hopelessness about the meaning of life. It therefore stands to reason that instead of achieving liberation from and victory over the principalities and powers, it is possible to become enslaved to them and to never have a taste of the joyous emancipation from all these powers which is made possible through the vicarious work of Christ on the cross.

\section{Implications for Christianity in Africa}

Like the Colossians, many Christians in Africa have subverted the uniqueness and supremacy of Christ. Christ's role in creation has been reduced, along with His ability to fully protect from the influences of unseen powers. Christ, in this reduced form, becomes a part of creation, not the Lord over it. Paul was at pains to counteract the erroneous ideas about Jesus and to exalt Him as unrivalled Lord of everything, the sole and sufficient mediator of salvation between God and His people. Therefore, the Pauline teachings in Colossians 1:12-23 hold important implications for Christianity in Africa.

First, Christians in African should realize that the essence of Christianity is neither a creed, nor a code, nor a cult. It is not primarily a system of any kind. "It is Christ. It is a person, and a personal relationship to that person”. The need for experiential knowledge of Jesus 
Christ cannot be overemphasised for without Him, one cannot be classified as a Christian.

Second, Christians in Africa should realize that the life of a true Christian must be in Christ. In other words the Christian must live in dynamic relationship with Him. The whole life of the Christian must be lived in His conscious presence. Just as a tree has its roots deep in the soil and draws its nourishment from it, so the Christian must be rooted in Christ, the source of his life and strength. In the same vein, just as a house stands fast because it is erected on a firm foundation, so the Christian life must be grounded on the strength of Christ so that it can resist any kind of storm, tempest, and tornados that life may offer. Christians in Africa should realize that Christ is both the source of the Christian life and the foundation of stability for all Christians.

Third, Christians in Africa should realize that when believers are part of the body of which Christ is the head, there is no need to fear, investigate, manipulate, and experiment with any other spiritual beings. Their case is as good as settled with the assurance of inner peace that springs forth and flows from the Prince of Peace who is living right inside of them.

Fourth, "all-round conquest and triumph of Christ resounds as a word of assurance to people for whom the supernatural powers loomed as constant threats to a tranquil and secure existence" (Abogunrin, pers. comm.). The already defeated host of darkness cannot harm the person who is in Christ, and their ultimate overthrow in the future is assured. Christians in Africa would do well to realize this indisputable truth.

Fifth, Christians in Africa have no cause to pay homage or to pledge allegiance to any lesser supernatural beings, be it divinities or ancestors. Jesus Christ is not one among the many competing gods or powers. He reigns supreme over every ruler and authority. He is wholly sufficient-he supplies all human needs and even more; and he is wholly other-he cannot be classified among his creation.

Sixth, Christians are not to follow ceremonies, rituals, initiations and restrictions in order to be saved. Christ is all that one needs in order to be saved.

Seventh, Christians in Africa must not obtain secret or acquire an exoteric knowledge in order to be saved or be liberated from the clutches of evil powers. They must not adhere to human wisdom, tradition, and philosophies. God's secret is Christ. Christ has been revealed to all. Human wisdom, tradition, and philosophies at best are vain speculations and at worst can be misleading given that they have human origin. In contradistinction to them, Christ's words are our ultimate example and authority.

Finally, Christians in Africa should shun combining aspects of several religions. They have everything since they have Christ. Jesus Christ is all-sufficient as He is also supreme above all else in creation, in time and eternity.

\section{Conclusion}

To counteract the heresies replete in Colossae, Paul portrays the uniqueness and supremacy of Jesus Christ. He graphically illustrated His supremacy both in creation and redemption. In creation, Christ is described as the image o $\mathrm{f}$ the invisible God, the firstborn over all creation, the Creator of all things, the goal of all things, one "before" everything, and the sustainer of all things. In redemption, Christ is presented as the head of the body, the Church, the beginning, the firstborn from the dead, the possessor of God's fullness, and the agent of God's reconciliation. In the light of these, and like Paul, we advocate the total adequacy and all-sufficiency of Christ in the African context, and we call for a much more serious Christian discipleship in African churches.

\section{References}

Abogunrin, S. O. 2002. Total Adequacy of Christ in the African Context. Lecture notes. University of Ibadan, Ibadan.

Achtemeir, P. J., J. B. Green, and M. M. Thompson. 2001. Introducing the New Testament: Its Literature and Theology. Grand Rapids: Eerdmans.

Alford, H. 1976. Alford's Greek Testament: An Exegetical and Critical Commentary, Vol. 3. Grand Rapids, Michigan: Guardian Press.

Awolalu, J. O. and Dopamu. 1979. West African Traditional Religion. Ibadan, Nigeria: Onibonoje Press.

Bandstra, A. J. 1974. Did the Colossians Errorists Need a Mediator? In New Dimensions in New Testament Study. R. N. Longenecker and M. C. Tenny, eds. Pp. 329-343. Grand Rapids, Michigan: Zondervan.

Barclay, W. 2009. The Letters to the Philippians, Colossians and Thessalonias. Bangalore: Theological Publications.

Bornkamn, G. 1948. Die haresie des kolosserbriefes. Thologische Literaturzeitung 73: 11-20.

Bruce, F. F. 1957. Ephesians and Colossians, NIC. Grand Rapids: Eerdmans.

Dibelius, M. 1975. The Isis Initiation in Apuleius and Related Rites. In Conflict at Colossae, $2^{d}$ edition. F. O. Francis and W. A. Meeks, eds. SBLSBS 4, Missoula, Mont: Scholars. 
Eadie, J. 1979. A Commentary on the Greek Text of the Bible of Paul to the Colossians. W. Young, ed. Grand Rapids, Michigan: Baker House.

Flemming, D. 2005. Contextualizing in the New Testament, Patterns for Theology and Mission. Downers Grove, Illinois: IVP Academic.

Harris, M. J. 2010. Exegetical Guide to the Greek New Testament: Colossias and Philemon. Nashville, Tennessee: Academic.

Houlden, J. L. 1970. Paul's Letters from Prison. London: Penguin.

Kasemann, E. 1964. Primitive Christian Baptismal Liturgy. In Essays on the New Testament Themes. Ernst Kasemann, ed. Pp. 149-168. Atlanta, Georgia: S.C.M.

Lightfoot, J. B. 1879. St. Paul's Epistles to the Colossians and to the Philemon, $3^{\text {rd }}$ ed. London: MacMillan.

Lohse E. 1971. Colossians and Philemon. Translated by W. R. Poehlmann and R. J. Karris. Philadelphia: Fortress.

Lyonnet, S. 1956. L'etude du Milieu Litterire et L'exegese du Nouveau Testament: Les Adversires de Paul a Colosses. Biblica 37: 27-38.

Moule, C. F. D. 1968. The Epistle of Paul to the Colossians and Philemon. Cambridge: Cambridge University Press.

O'Brien, P. T. 1982. Colossians, Philemon. Word Bible Commentary 44. Waco, Texas: Word Books.

Wright, T. N. 1986. The Epistles of Paul to Colossians and to Philemon: An Introduction and Commentary. Grand Rapids, Michigan: Eerdmans.

Zan, J. L. 1970. Introduction to the New Testament. Grand Rapids: Michigan.

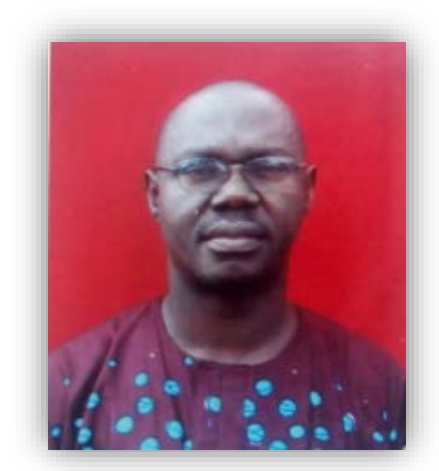

Valentine Chukwujekwu Mbachi (Ph.D), lectures in New Testament Studies in the Department of Religious Studies in the Faculty of Arts, Nnamdi Azikiwe University, Awka, Nigeria.

Author email: valmbachi@gmail.com vc.mbachi@unizik.edu.ng

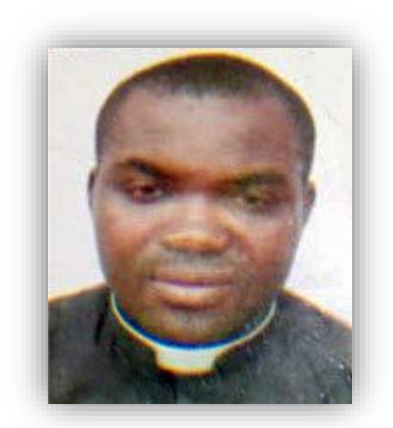

John Uchendu is a Ph.D student of Nnamdi Azikiwe University, Awka, Nigeria.

Author email: onyiij85@gmail.com 